\title{
Influence of School Operational Assistance Fund (BOS) Management on the Student Grade Advancement in Fatuleu State High School 1, Kupang District
}

\author{
Johanis Taek* Lenny M. Tamunu Petrus Kase \\ Master's Program in Administrative Science, Postgraduate Program, Universitas Nusa Cendana Kupang, Nusa \\ Tenggara Timur, Indonesia
}

\begin{abstract}
This study aims to analyze the influence of School Operational Assistance (BOS) funds management on the Grade Advancement rate of the underprivileged students in SMA I Fatuleu (Fatuleu State High School 1), Fatuleu District, Kupang Regency, NTT Province. This research is a descriptive correlational study, using a quantitative approach. The location of this research was Fatuleu State High School 1, located in Fatuleu District, Kupang Regency. The sampling method used in this study was a probability sampling method with a simple random sampling technique. The collected data were processed using a computer with the following stages of analysis; (1) Univariate Analysis; (2) Bivariate Analysis; (3) Multivariate Analysis.Research result exhibited simultaneously a significant influence between Organizing, Planning and Monitoring and Evaluation on the timeliness of the Grade Advancement Rate of Underprivileged Students in Fatuleu State High School 1; there is a significant influence between planning variables on the timeliness of the Grade Advancement Rate of Underprivileged Students in Fatuleu State High School 1; there is a significant influence between the Organizing variables on the timeliness of the Grade Advancement Rate of Underprivileged Students in Fatuleu State High School 1; there is no significant influence between the monitoring and evaluation variables on the timeliness of the Grade Advancement Rate of Underprivileged Students in Fatuleu State High School 1.
\end{abstract}

Keywords:Management; School Operational Assistance Fund; Grade Advancement; Planning; Organizing; Monitoring.

DOI: $10.7176 / \mathrm{PPAR} / 9-3-13$

Publication date:March $31^{\text {st }} 2019$

\section{INTRODUCTION}

The education cost is one of the important aspects in achieving educational goals, as it will be used to finance all education funding. One of the main problems in financing education is to meet the school investment, operational, and needs. It is necessary to protect the community, especially the poor, fighting for their rights to obtain proper education in elementary school, junior high school, and high school levels.

The government's effort, in this case, the Ministry of Education and Culture, to overcome this issue is to provide School Operational Assistance Funds (BOS) to registered schools. The BOS funds provided by the Ministry of Education and Culture are referred to as National BOS or later in this study referred to as BOS. In addition to National BOS, there is BOSDA (BOS Regional) provided by the Regional / Provincial Governments. (Yuliani, 2009).

One indicator of accelerating completion of compulsory education can be measured by achieving a Gross Enrollment Rate (APK). The APK is the proportion of the number of students at a particular level of education compared to residents of a certain age. According to the Ministry of Education and Culture (bos.kemdikbud.go.id; accessed on November 19, 2017), the number of elementary schools APKs in 2005 has reached $115 \%$ while a junior high school in 2009 has reached $98.11 \%$. The 9-year compulsory education program has been completed 7 years earlier than the planned target. BOS funds accelerate the completion of 9year compulsory education in Indonesia. Nevertheless, there is a huge number of junior high school graduates who drop out of school and do not continue to the high school level. For this reason, the government has launched and implemented a Universal Secondary Education (PMU) program since 2013. It targeted 97\% APK for secondary education or high school/equivalent level by 2020. As an illustration, in 2015/2016 APK for secondary education (high school / equivalent) is 79,7\%.(http//www.bos.kemdikbud.go.id).

The Data and Statistics Center of the Ministry of Education and Culture (Kemendikbud) in February 2017, stated that in 2016 the Province of Nusa Tenggara Timur (NTT) was included in the top ten namely, ranked 8th Province with the lowest APK $72.81 \%$. In 2015 it amounted to $74 \%$ and in 2014 was $71.40 \%$. It can be concluded that in within 2014-2016 period, the APK of SMA / equivalent level in NTT Province experienced fluctuating conditions. Kupang Regency APK in 2014 was $79.15 \%$, 2015 was $81.40 \%$, and 2016 was $81.51 \%$. (http // www.bos.kemdikbud.go.id).

To achieve this target, the government is obliged to provide the widest and fairest access for all people, including junior high school graduates encouraging them to obtain a secondary education. One of the 
government's concerns is to increase the ability of the community to continue their education to secondary level (high school/equivalent). For this reason, the government implemented the BOS Middle School program (BOS SM). PMU aims to provide service, expansion, and equal opportunity to obtain quality secondary education for every Indonesian citizen. To achieve this, the government compiled the BOS SM program. It was distributed to all high schools and vocational schools, both public and private throughout Indonesia. BOS funds granted to High Schools are called BOS High School (Yuliani, 2009).

To determine the extent BOS implementation can affect the Grade Advancement rate of underprivileged students in terms of aspects of BOS management, a comprehensive evaluation of the activities of school management on the implementation of BOS allocations is required. Management is a series of activities carried out by schools in a transparent manner, starting from the process of planning, organizing, leadership, and controlling the efforts of the members of the school organization as well as the use of the resources available at the school to achieve the stated goals. Evaluation is an investigation of an event to determine the real situation. Evaluation is used to produce and present information to provide the basis of policymakers in making a decision. Evaluation is also used to determine the benchmark for the success of the implementation and determination of policy. BOS management evaluation is a means to determine benchmarks and the level of success of managing a program.

An evaluation of BOS management is important. Nevertheless, many parties have not yet implemented an evaluation of the implementation of BOS funds management. One of the schools that received high school BOS funding in 2017 is Fatuleu State High School 1. For this reason, Fatuleu State High School 1 is required to manage BOS funds in accordance with good and correct management principles and transparency to all school members. Fatuleu State High School 1 is located in the Fatuleu district and is directly adjacent to Oelamasi City as the center of the Kupang District government. There are 26 classrooms in the school. Each class has a capacity of \pm 30 student.

\section{REVIEW OF LITERATURE Management}

Management is a process in planning to achieve certain goals. Etymologically, "management" comes from the word to manage, which means regulating. Management is carried out through a process and managed based on the order and function of the management itself. While in terms of terminology, there are several definitions of management proposed by experts. Hasibuan (2012) described management as science and art that regulates the process of utilizing human resources and other sources effectively and efficiently to achieve a certain goal. According to G.R Terry (in Purwanto, 2006), management is a process that distinguishes planning, mobilizing, organizing, and monitoring by utilizing both science and art in order to achieve the goals previously set.

According to G.R Terry (in Purwanto 2006), management functions are Planning, Organizing, Actuating, and Controlling. Henry Fayol's (in Purwanto, 2006) mentioned five management functions, including Planning, Organizing, Commanding, Coordinating, and Controlling. The management functions basically have similarities that must be implemented by each manager in sequence to ensure the management process is implemented properly (Hasibuan, 2012).

\section{Education Financing Management}

Rohiat, (2012), states that Through financial management activities the funding needs of school/madrasah activities can be planned, sought to be procured, booked transparently, and used to finance the implementation of school/madrasah (Muslim School) programs effectively and efficiently. For this reason, the objectives of financial management are: (1) increasing the school finance usage's effectiveness and efficiency; (2) increasing accountability and transparency; and (3) minimize misuse of school budgets.

To achieve this goal, the creativity of the principal/madrasah is needed by exploring the sources of funds, appoint treasurer in bookkeeping and financial accountability, utilizing it properly according to the applicable laws and regulations. The school or madrasah must perform correctly to ensure financial management targets, such as: (1) ensuring that available funds are used for daily activities of the school or madrasah and using excess funds to be reinvested; (2) maintaining school assets; and (3) ensure the rules and practices of bookkeeping are known and implemented.

Through financial management activities, school/madrasah funding activities can be planned, sought to be procured, booked transparently, and used to finance the implementation of school/madrasah programs effectively and efficiently. For this reason, the objectives of financial management are: (1) increasing the effectiveness and efficiency of the use of school finance; (2) increasing accountability and transparency of school finance; and (3) minimize misuse of school budgets.

Fattah (2004) stated the source of education funding is parties who provide subsidies and donations regularly. The fund sources consist of the central government (APBN), regional government (APBD), parents (Committee), and the community. Funds sourced from the central government consist of salaries, subsidies, or assistance in financing the implementation of SDN (SBPP-SDN), Maintenance Care Funds (DOP). From this 
understanding, the education fund sources for either schools or madrasas are the responsibility of the central government, regional government, and society. Whereas the source of the BOS funds in SMA / MI is centered on the central government.

\section{Student Participation}

Participation is partaking or participation, Suryosubroto, (in Saifurrijal, 2012). According to Keit Davis (in Safurrijal, 2012), participation is a person's mental and emotional involvement in achieving goals and taking responsibility in them. According to Tjokrowinoto (in Safurrijal, 2012). Participation is the mental and emotional inclusion of a person in a group situation that encourages them to develop their thought process and feelings for achieving goals, jointly responsible for that goal.

In essence, learning is the interaction between students and their environment. Therefore, to achieve optimal learning outcomes require student involvement or participation. Student involvement is very important to determine the success of learning. Student participation is the involvement of students in the learning process to achieve satisfying learning outcomes, (Yamin, 2007).

Yamin (2007), classifies participation activities in the learning process as follows: (1) Visual activities; Reading, viewing pictures, observing experiments, demonstrations, and watching other people work or play. (2) Oral activities; Expressing a fact or principle, connecting a goal, asking a question, giving advice, expressing opinions, interviews, discussions, and interruptions. (3) Listening activities; Listen to the study material presentation, listen to conversations or group discussions, listen to a game, listen to the radio. (4) Writing activities; Write stories, write reports, examine essays, copy material, make summaries, do tests, and fill in questionnaires. (5) Drawing activities; Drawing, making graphics, charts, map diagrams, and patterns. (6) Metric activities; Conduct experiments, choose tools, carry out the task, dance and gardening. (7) Mental activities; Reflect, remind, solve problems, analyze factors, see relationships, and make decisions. (8) Emotional activities; Interest, differentiation, courage, calm, etc. Activities in this group are overlapping with each other.

\section{High School School Operational Assistance (BOS)}

According to Minister of National Education Regulation number 69 of 2009, BOS is a government program which provides funding for non-personnel operating costs for basic education units as implementers of compulsory education programs. The standard non-personnel operating costs are the standard costs needed to finance non-personnel operations for 1 (one) year as part of the overall education fund to ensure the education unit capable to carry out educational activities regularly and sustainably in accordance with the National Education Standards.

According to the Technical Guidelines for School Operational Assistance (BOS) in 2017 the purpose of high school BOS is divided into two: general purpose and special purpose. In general, the aim of BOS High School is to create affordable and quality education services for all levels of society in Indonesia. While the specific objectives of BOS High School are: (1) Helping operational costs of non-school personnel. (2) Reducing the high school students drop out rate. (3) Increase the Gross Enrollment Rate (APK) of high school students. (4) Realizing governmental affirmative action for high school students by reducing school fees. (5) Providing opportunities for high school students to obtain affordable and quality education services. (6) Improve the quality of the learning process in schools.

BOS is used to help meet the operational needs of non-personnel schools. The BOS High School funds objective is in accordance with the Regulation of the Minister of National Education Number 69 of 2009 concerning Standard Non-Personnel Operating Costs for 2009 for SMP / MTs, SMA / MA, SMK, SDLB, SMPLB, and SMALB.

Based on 2017 BOS High School Technical Guidelines, it is stated that at the school level, the management of the BOS program is carried out by a committee formed by the Principal. The committee consisted of school principals, deputy principals, teachers, and school committees. The composition of the committee is as follows: (1) The Principal is responsible for the program. (2) Deputy headmaster or relevant teacher as chair of the executive committee. (3) The teacher acts as a supervisor. (4) The routine treasurer of the school or treasurer specially appointed by the principal as the financial manager.

In the BOS program, funds received by the school as a whole and managed independently by the school involving the board of teachers and school committees. Thus, the BOS program strongly supports the implementation of School-Based Management, which generally aims to empower schools through authorization (autonomy), giving greater flexibility to manage school resources, and encouraging the participation of school staff and communities to improve the quality of education.

\section{RESEARCH METHOD}

This research was a descriptive correlational study, using a quantitative approach (Sugiyono, 2012). The location of this study was at SMA 1 Fatuleu, located in Fatuleu District, Kupang Regency which had a total number of 746 active students. The class details are as follows: class X: 273 people, class XI: 237 people and class XII: 236 people. The population in this study were all active students of class X, XI, and XII. These students are a 
member of underprivileged families and were registered in the profile of SMA 1 Fatuleu in 2017 as recipients of high school BOS funds. The total BOS funds recipients were 307 students. The sampling method used in this study was a probability sampling method with a simple random sampling technique. In this technique, sampling is done randomly (Simple random sampling) using the Slovin formula. The variables in this study consisted of independent variables and dependent variables. The independent variables in this study were (1) Planning (funding/financing, human resources, facilities/infrastructure and support for school residents). (2) Organizing (Job Description) (3) Monitoring and Evaluation. The dependent variable was the Grade Advancement rate of students from disadvantaged groups in Fatuleu State High School 1. The instrument used in this study was a questionnaire with interview guidelines. The data collected was processed using a computer with the following steps (Notoatmodjo, 2010); ( 1) Data checking (editing) (2) coding (3) data entry into the computer (entry); (4) data cleaning; (5) tools used to analyze. Data collected was processed using a computer with the following stages of analysis (Notoadmodjo, 2010); (1) Univariate Analysis; (2) Bivariate Analysis; (3) Multivariate Analysis.

\section{FINDING AND DISCUSSION}

The Influence of School Operational Assistance Fund Planning on the Grade Advancement of Underprivileged Students in Fatuleu State High School 1

Research result exhibited that the majority of respondents had a good assessment of the planning of BOS funds. 27 people rated adequately good (15.5\%). 61 people rated good (35.1\%). 81 people $(46.6 \%)$ rated Very Good. 2 people rated Very Bad (1, 1\%), 3 people rated Bad (1.7\%). The results of the statistical test exhibited that variable has an effect on the level of timeliness of the Grade Advancement of underprivileged students in I Fatuleu State High School because it has a ratio $>$ i.e., 2,752 and in the evidence, interval includes number 1 $(1,342-5,645)$. This variable also has a significant effect on the timeliness of the Grade Advancement Rate of underprivileged students in I Fatuleu State High School with $\mathrm{P}=0,000(\mathrm{P}<0.05)$.

Fatuleu State High School 1 has implemented a good and transparent plan and involves all elements of the school community in determining the formulation of BOS budget allocation according to the technical guidelines (BOS) for the management of BOS funds. It ensures that it has an impact on the high level of underprivileged students' Grade Advancement. 150 students completed their studies on time and 24 people were not on time.

Technical Guidelines for BOS High School 2017 state that at the school level, the management of the BOS program is carried out by a committee formed by the Principal. The committee consisted of school principals, deputy principals, teachers, and school committees. The amount of BOS funds per student fluctuates in each budget year, depending on government policy. The use of BOS funds schools must adhere the technical guidelines for managing BOS funds. Indicators of the transparency and accountability of BOS funds are as follows: The School Committee approves the School Budget Plan and the Chairperson of the School Committee or its representatives to sign the RAPBS. The School Committee reviews the school financial report. The Chairperson of the School Committee or its representatives observe or provide input into the school's financial statements. The chairman of the committee approves the school's financial report and the head of the school committee or his representative signs the school financial report.

The school announces the use of funds on the School bulletin board, where the announcement is regularly updated and the bulletin board is placed in a place that can be accessed by many people. Nevertheless, Fatuleu State High School 1 had carried out the management of BOS funds well according to the technical instructions (Reporting Application and School Information Management) that had been socialized by the related agency. Information disclosure as a form of transparency in managing BOS funds at Fatuleu State High School 1. It provides information regardings aspects which may or may not be funded using BOS, through fund usage report. These are updated regularly through school bulletin boards to ensure it could be accessed by the school community, especially parents.

In BOS funds planning, the principal first adjusts to the overall school development plan, both short-term and long-term development in the form of five-year, ten-year and twenty-five years development. BOS funds could be managed well using the plan. The use of BOS funds must be based on mutual agreement and decision between the school management team, the teacher board, and the school committee. The result of the agreement must be in the form of the minutes of the meeting and signed by all participants. BOS funds could not cover every school needs, as it is merely components of certain activities, such as the purchase/procurement of textbooks, student learning and extracurricular activities, school care, monthly payment of honorary teachers, etc. Effect of Organizing on the Grade Advancement at Fatuleu State High School 1

Research result exhibited that most respondents had a good assessment of the organization (job description) in managing BOS funds. 34 people (19.5\%) rated adequately good category. 88 people (50.6\%) rated good category. 45 people $(25.9 \%)$ rated very category. 1 rated very bad $(0.6 \%)$ and 6 people $(3.4 \%)$ rated not good.

The results of statistical tests exhibited that this variable has an effect on the level of timeliness of the Grade Advancement of underprivileged students in Fatuleu State High School I because it has a ratio of $>2,735$. The evidence interval includes number $1(1,256-5,956)$. The organizing variable (job description) has a significant 
effect on the timeliness of the Grade Advancement of underprivileged students in Fatuleu State High School I with $\mathrm{P}=0,000(\mathrm{P}<0.05)$.

Based research result, Fatuleu State High School 1 Kupang District was included in the good criteria. This exhibited that the majority of underprivileged students in Fatuleu State High School 1 have good perceptions and a high level of trust in the school. The BOS fund management committee provides optimal education services for the student needs, especially those from poor families.

The process of managing School Operational Assistance funds must be carried out jointly by a group of people (Teachers) who are members of an organization. The BOS management committee ensure that the activities are maintained well. It would create harmonious working conditions without sacrificing the human elements involved in educational activities. The process is carried out in order to achieve a predetermined goal, which in this case includes general objectives "general purpose scale" and carried out by each educational organization "special purpose scale". The management process is carried out to ensure that the objectives can be achieved effectively and efficiently.

Management of BOS funds at Fatuleu State High School 1 is carried out by all teachers in charge and have been given responsibility and trust. In carrying out the management, the teacher is merely the program implementer who cooperates with the committee and student guardians to create transparency. It is conducted to minimize the occurrence of fraud. It means that transparency ensures program implementers, namely teachers, will be more focused to create organizational effectiveness in managing BOS funds.

The provision of BOS funds must also be immediately realized in accordance with the agenda designed, regarding provision of student assistance, facilities, and infrastructure improvement. BOS funds are intended to improve the learning process in accordance with the objectives of BOS funding. Therefore, it ensures that the level of productivity of the BOS funds management will be realized. Especially in utilizing School Operational Assistance for students from a disadvantaged family. Therefore these students may complete their study effectively and efficiently.

The Influence of Monitoring and Evaluation Variables on the Grade Advancement in Fatuleu State High School 1 Kupang Regency

The research results exhibited that 2 respondents rated very poor (1.1\%), 4 people rated bad (2.3\%), 25 people rated adequately good 25 (14.4), 54 people rated good (31.0\%), 89 people $(51.1 \%)$ rated very well. Based on statistical analysis exhibited that the Monitoring and Evaluation variable (MONEV) has no significant effect on the timeliness of Grade Advancement of underprivileged students in Fatuleu I State High School with $\mathrm{P}=0.428$ $(\mathrm{P}<0,05)$.

The underprivileged students Fatuleu State High School 1 Grade Advancement are not dependent on Monitoring activities and Evaluation of BOS fund management carried out by related parties. Because they have an average good judgment and a high level of trust regarding the planning of BOS funds by BOS fund management committee. They considered that the assistance provided was sufficient to meet the needs of the school. Therefore the students made every effort to utilize the assistance provided in completing the school in accordance with the specified time.

Monitoring and Evaluation have very important roles and functions, especially to ensure the ongoing activities is truly in accordance with the objectives of the program. Monitoring can be referred to as "ongoing evaluation," which is done while the activity takes place to make improvements "on the go" if needed. The intended evaluation is "terminate evaluation," carried out at the end of the program to ascertain whether the implementation and benefits of the program are in accordance with the objectives or not. The results of the evaluation can be used as input for planning the next program.

Supervision of the management of BOS funds in Fatuleu State High School 1 is done by comparing data on planned school activities and budgets prepared in advance with reports on school budget usage. This supervision was carried out with the aim of evaluating the results of the school organization's performance while managing the BOS funds at Fatuleu State High School 1.

\section{Dominant Influence of Planning and Organizing on Grade Advancement Rate of underprivileged students in Fatuleu State High School 1}

Based on the modeling results using logistic regression, it is known that the factors that consistently have a significant effect on the Grade Advancement Rate of students in disadvantaged groups are variables with $\mathrm{p}<0.05$, which is the planning variable of BOS funds value $(p=0.006)$ and organizing variables BOS funds with $p=$ 0.011 . Whereas the variable that has the greatest ratio $(\mathrm{R})$ is the variable that most influences the timeliness of the study of the underprivileged students. Therefore the results of the modeling determined that the planning variable of BOS funds is the variable that most influences the level of completion of studies of underprivileged students with an R-value of 2.752 and the variable organizing BOS funds with a value of R 2.735 .

National education standards exhibited that a planning process is an essential tool in school management. In relation to the management standard of the education unit, the institutional development planning system implemented in each school must be able to facilitate and accommodate the five main pillars outlined in the 
management standards, namely: independence, partnership, participation, transparency and accountability.

The education management perspective emphasizes that Organizing is an essential aspect that determines the achievement of a predetermined plan. Stephen J. Kneziech stated that management of education is a set of organizational functions which main goal is to ensure the efficiency and effectiveness of education services, as well as implementing policies through planning, decision making, leadership behavior, preparation of resource allocation, stimulation and coordination of personnel, ensures conductive organizational climate, and determine the essential change of facilities to meet the needs of students and society in the future.

The results of this study are in line with the technical guidelines for managing Middle High School Operational Assistance (BOS SM). The general purpose of BOS SM is to realize affordable and quality education services for all levels of society in order to support a 12-year compulsory education program. The extent to which BOS funds can support school operational activities in order to realize the 12-year compulsory education program. This depends on the school's compliance in implementing BOS funds as regulated in the 2015 BOS technical guidelines, both from the destination and designation.

The requirement of the Grade Advancement timeliness for underprivileged students is different compared to students from the upper middle class. The main problem experienced by underprivileged students is their limited economic aspect, causing difficulty to access information outside school regarding study material. Student guardian or parents must spend a larger sum of money on high school student compared to the middle high or elementary school level.

In addition, facilities, transportation, accommodation, and study material sometimes does not support students to learn independently at home. These factors must be the prioritized in formulating school planning regarding the allocation of School Operational Assistance. It is conducted in order to support underprivileged students Grade Advancement in timely need.

\section{CONCLUSION}

Based on the results of the research and discussion above, the following conclusions were obtained:

1. There is simultaneous influence between Organizing, Planning and Monitoring and Evaluation on the timeliness of the Grade Advancement Rate of Underprivileged Students in Fatuleu State High School 1.

2. There is significant influence between the planning variables on the timeliness of the Grade Advancement Rate of Underprivileged Students in Fatuleu State High School 1.

3. There is significant influence between the Organizing variable on the timeliness of the Grade Advancement Rate of Underprivileged Students in Fatuleu State High School 1.

4. There is no significant influence between the monitoring and evaluation variables on the timeliness of the Grade Advancement Rate of Underprivileged Students in Fatuleu State High School 1.

\section{SUGGESTION}

Based on the research result and discussion above, recommendations obtained are described as follows:

1. Fatuleu State High School 1 utilize BOS funds to optimize the timeliness of underprivileged students' Grade Advancement. It takes a strong commitment from the school as an educational institution that manages BOS funds in formulating careful planning.

2. Planning for Fatuleu State High School 1 School Operational Assistance should be through group discussion in determining the budget allocation for School Operational Assistance funds by involving all school members (School Committee). Therefore the planning is formulated according to the school needs and prioritizes students from disadvantaged groups.

3. Fatuleu State High School 1 Principal recruits BOS funds committee transparently and consider competency, credibility, and accountability aspects of each member. It ensures effective and efficient process in managing BOS funds.

4. The Nusa Tenggara Timur Province (NTT) education office should routinely involve the school principal, the BOS committee and the School Committee in monitoring and evaluating the BOS program at Fatuleu State High School 1.

\section{REFERENCES}

1. Yuliani Desi. 2009. Hubungan Program Bantuan Operasional Sekolah (BOS) SD-SMP dan angka Partisipasi Kasar Terhadap Indeks Pembangunan Manusia (IPM) di Lampung tahun, (2009).

2. Hasibuan, Malayu. 2012. Manajemen Sumber Daya Manusia. PT Bumi Aksara, Jakarta.

3. Purwanto, Ngalim. 2006.. Administrasi dan supervises pendidikan. Remaja Risda karya, Bandung.

4. Purwanto, Ngalim. 2006. Ilmu pendidikan teoritis dan praktis. Remaja Risda karya, Bandung

5. Rohiat. 2009. Manajemen Sekolah. PT RefikaAditama, Bandung.

6. Fatah, Nanang, 2004. Landasan Manajemen Pendidikan. Edisi ketujuh, Remaja Rosda karya, Bandung.

7. Saifurrijal S. Model Deep Dialog/Critical Thinking (DD/CT) dengan metode think pair share untuk 
meningkatkan partisipasi dan hasil belajar pada siswa SMK N 2 Pengasih tahun ajaran 2012/2013.

8. Yamin, Martinis. 2007. Profesionalisme guru dan implementasi KTSP. Persada Gaung Press. Lapis PGMI. Modul pembelajaran IPA paket 2, Jakarta

9. Sugiyono.2013. Metode Penelitian Pendidikan. Alfabeta, Bandung.

10. Notoatmodjo, S. 2010. Metodologi Penelitian Kesehatan. Rineka Cipta, Jakarta. 